\title{
An objective chemistry: what T. S. Eliot borrowed from Schopenhauer
}

\author{
Aakanksha Virkar-Yates
}

\begin{abstract}
Tradition and the Individual Talent" (1919) is T. S. Eliot's expression of his poetics of impersonality, a spirited rejection of romantic subjectivism and emotionalism. But could Eliot's modernist essay be derived in part from what he presents as the unremittingly "emotional" philosophy of Schopenhauer? Section 51 of Schopenhauer's The World as Will and Representation I (1818) presents a metaphor resoundingly familiar to modern readers: the chemistry of verse-writing. A closer examination of "Tradition" and "Hamlet and his Problems" (1919) betrays Schopenhauer's unacknowledged role in Eliot's dictums of impersonal emotion and the "objective correlative."
\end{abstract}

In his 1926 lectures on metaphysical poetry, Eliot describes the work of Jules Laforgue as the "nearest verse equivalent to the philosophies of Schopenhauer and Hartmann;" a literary rendition of their philosophies of the unconscious and of annihilation. (1) Yet, Eliot suggests, in Laforgue the system of Schopenhauer ultimately collapses; the poet does not find in the philosopher that metaphysical balance between thought and feeling he so desperately craves. Schopenhauer's philosophy, Eliot asserts, is "muddled by feeling - for what is more emotional than the philosophy of Schopenhauer or Hartmann?” (2) Here, as elsewhere, Eliot paints Schopenhauer as a despairing, overwrought romantic. Such a presentation naturally makes Schopenhauer an unlikely figure to have any bearing on the great central theme of Eliot's poetics - his theory of impersonality. In actual fact, Eliot's formulation of impersonal emotion in "Tradition and the Individual Talent" (1919) borrows much from Schopenhauer's aesthetics of poetry in The World as Will and Representation (1818).

Schopenhauer's metaphysics of the will are well known. In his philosophical opus of 1818, Schopenhauer portrays the will as a blind, striving urge to life, determining human experience and perpetuating an endless cycle of desire, pain and suffering. It is this romantic pessimism and metaphysics of despair that had so great an impact on writers and artists of the nineteenth and twentieth centuries. Ironically perhaps, liberation from the will and suffering is suggested by Schopenhauer to be found in three ways: through compassion, ascetic renunciation and aesthetic experience. In his celebration of renunciation and the denial of the will to live, Schopenhauer famously embraces Buddhism and the religion of the Upanishads. Eliot himself describes Schopenhauer's view of Buddhism as "romantic misunderstanding," but it nevertheless conditions his own engagement with Indic tradition. (3) A similar tension is visible also in what J. M. Kertzer suggests to be Eliot's modification of F. H. Bradley's arguments against Schopenhauer's conception 
of the will. (4) Kertzer reads Ash-Wednesday as reflecting Schopenhauer's problematical conception of the will and asceticism; self-denial is the paradox that makes the will both the damnation and salvation of the individual. Kertzer goes so far as to suggest that this problematical notion is in part the grounds for Eliot's move from philosophy to theology. Questions of Eliot's aesthetics in the light of Schopenhauer have, however, been almost entirely neglected.

For Schopenhauer, the realm of the aesthetic offers a form of knowledge truly exceptional. In general human experience, the world and its objects are conceived spatiotemporally and in utilitarian relation to the needy will. In striking contrast, aesthetic experience predicates the freedom of the intellect from the tyranny of the will: the "subject of knowing" detaches itself from the "subject of willing." The result is a pure, will-less, form of knowing in which the transformation of the subject is matched by that of the object; through the individual thing in space and time is perceived the objective Platonic Idea - the original and eternal form. The Ideas, Schopenhauer writes, are "truly existing, since they always are but never become and never pass away." (5) Critically, unlike Plato, who reserves the Ideas for intellection, Schopenhauer stresses that the Platonic Ideas can only be perceived in the aesthetic experience of nature or art. Only in such experience do we "no longer consider the where, the when, the why, and the wither in things, but simply and solely the what." (WWR I, p. 178). This non-conceptual knowledge or knowledge of perception, which Schopenhauer also refers to as "intuitive cognition" or "feeling," is what makes for the exceptional domain of the aesthetic. Unlike concepts which are abstracted, the Ideas can only be perceived. Knowledge of these Ideas and of the true and essential nature of the world is the knowledge afforded, par excellence, by aesthetic experience. The artist, moreover, not only perceives the Ideas of the world (like individuals of genius), but is further able to fashion these Ideas in art in a manner that makes them accessible to the art receiver. This fashioning is often through the use of images. Notably, Schopenhauer reverses Plato's hierarchy in extolling images as a means by which the ordinary intellect may be directed upward to the apprehension of the Ideas.

Broadly speaking, Schopenhauer's view of aesthetic experience as the perception of objective Ideas by a "will-less" subject shows some similarity with Eliot's ideas of objectivity and impersonality in “Tradition and the Individual Talent" (1919). This point has been made by Thomas Lütkemeier who suggests that Eliot and Schopenhauer "share the goal of depicting the notion of a form of objectivity in the aesthetic forms of knowledge and expression." (7) Beyond this broad congruence, however, Lütkemeier suggests that Eliot takes a very different path; while Schopenhauer's aesthetic theory focuses on perception, Eliot's essay offers an account of aesthetic expression. Contrary to 
Lütkemeier's reading, however, Section 51 of $W W R$ I may be seen to consider precisely the question of aesthetic expression in the art of poetry. The aesthetics of poetry is also the subject of Section 37 of WWR II and together these examinations of poetry are the sections most likely to have made a lasting impression on Eliot's mind. Indeed it is to Section 51 in particular that Eliot's "Tradition" essay seems to be curiously allied, in its complex formulation of emotion, feeling and image, and in an intriguing coincidence of metaphor. At the opening of Section 51, Schopenhauer explains how poetry allows for the perceptual apprehension of the Idea, despite using the abstract concepts of language.

Ideas are essentially perceptive; therefore, if in poetry only abstract concepts are directly communicated by words... the abstract concepts ... must be so arranged that their spheres intersect one another... but instead of it a perceptive representative appears before the imagination, and this is then modified further and further by the words of the poet according to his intention. Just as the chemist obtains solid precipitates by combining perfectly clear and transparent fluids, so does the poet know how to precipitate, as it were, the concrete, the individual, the representation of perception, out of the abstract, transparent universality of the concepts by the way in which he combines them... The skill of a master in poetry as in chemistry enables one always to obtain the precise precipitate that was intended. (WWR I, pp. 242-43)

Schopenhauer describes how, through the concepts of language, the poet-chemist conjures before the imagination an individual, immediate object of perception: a "perceptive representative" or, more simply, an image. While using the abstract concepts of language, the skilful poet can yet "precipitate" out precise images in the minds of his readers. Turning to "Tradition and the Individual Talent," we find Eliot's famous depiction of poetic creation as chemical process. This poetic chemistry pertains specifically to what Eliot describes as the second aspect of his impersonal theory of poetry: the relation of the poem to its author. Here, he characterises the mind of the mature poet as

.... a more finely perfected medium in which special, or very varied, feelings are at liberty to enter into new combinations.

The analogy was that of the catalyst. When the two gases previously mentioned are mixed in the presence of a filament of platinum, they form sulphurous acid... the platinum itself is apparently unaffected: has remained inert, neutral, and unchanged. The mind of the poet is the shred of platinum... the more perfect the artist, the more completely separate in him will be the man who suffers and the mind which creates; the more perfectly will the mind digest and transmute the passions which are its material. (8)

Like Schopenhauer, Eliot emphasises an objective model of aesthetic experience, distancing personal suffering (or willing) from artistic creation. In my view, Eliot's representation of poetry through the analogy of a chemical reaction is intriguingly similar to Schopenhauer's metaphorical formulation. Both writers describe the making of poetry as a chemical process that involves the 
amalgamation of elements to form "precise precipitates" or "new combinations." In both cases, the vision of artistic creation is notably similar in tone, with an atmosphere of scientific precision and impersonality. It is almost as if Eliot has read Schopenhauer's metaphor and taken it a step back in time. Schopenhauer describes how the poet combines words as a chemist combines fluids, evoking precise images in the mind of the reader through which the Idea is perceived. Eliot begins in the moment preceding this, with the passions that are transmuted to form new compounds within the medium of the poet's mind. The business of the poet, according to Eliot, is to use "ordinary" emotions and "in working them up into poetry, to express feelings which are not in actual emotions at all." (p. 21) In the "Tradition" essay, it becomes increasingly clear that these compounds of feeling are frequently formulated through the image, making Eliot's chemical equation even closer to Schopenhauer's than it appears on first reading.

The effect of a work of art...may be formed out of one emotion, or may be a combination of several; and various feelings, inhering for the writer in particular words or phrases or images, may be added to compose the final result. Or great poetry may be made without the direct use of any emotion whatever: composed out of feelings solely...The last quatrain gives an image, a feeling attaching to an image, which 'came', which did not develop simply out of what precedes, but which was probably in suspension in the poet's mind until the proper combination arrived for it to add itself to. The poet's mind is in fact a receptacle for seizing and storing up numberless feelings, phrases, images, which remain there until all the particles which can unite to form a new compound are present together. (pp. 18-19)

In this passage, Eliot moves almost imperceptibly between the mind of poet and reader, discussing the "effect" of a work of art as based pre-eminently on feeling. The movement of thought is similar to Schopenhauer's portrayal of the effect of poetry as the conjuring of perceptive representatives in the mind of the reader. In his well-known book, The New Poetic, C. K. Stead observes that in Eliot emotion is personal and feeling impersonal. As seen, Eliot believes that emotions are aesthetically transformed, worked up into feelings. The "Tradition" essay further suggests this process of depersonalization to be intimately linked with the image. Notably, it is in this unification of feeling and image that a Schopenhauerian chemistry resurfaces. Eliot describes "a feeling attaching to an image" as a "combination" probably already "in suspension" in the poet's mind; "feelings, phrases, images" are "particles" in the forming of "new compounds." The making of poetry as envisioned by Eliot is a continuing chemistry that yields a compound of feeling; a compound that is frequently visual, chemically formulated and objectively perceived. As such, it is effectively the equivalent of the perceptive representatives or images by which Schopenhauer suggests poetry to work. Indeed, much as Schopenhauer stresses the importance of images in apprehending the Idea, for Eliot it is these feelings that are essential to art; for great poetry may forsake emotion and be "composed out of feelings solely." 
What I am suggesting is that Eliot creatively appropriates Schopenhauer's formulation of poetry as chemistry, depicting feeling as a pre-eminently visual compound precipitated in the mind of poet and reader alike. After all, this equivalence is the very proposition of Eliot's "objective correlative," as suggested in the companion piece, "Hamlet and his Problems" (1919; reprinted as "Hamlet" in the Essays of 1932). As Eliot famously writes, "The only way of expressing emotion in the form of art is by finding an 'objective correlative'; in other words, a set of objects, a situation, a chain of events which shall be the formula of that particular emotion; such that when the external facts, which must terminate in sensory experience, are given, the emotion is immediately evoked." ("Hamlet," Essays p. 145) A central precept of Eliot's poetics, the objective correlative is perhaps even more reminiscent of Schopenhauer's chemical analogy. This too is a "formula" that seemingly guarantees a specific outcome in the mind of the reader, much in the vein of Schopenhauer's chemically configured perceptive representatives. The objective correlative describes how poetry makes emotion an object of knowledge for another. The association of emotion and object is equivalent to the compound of feeling and image presented in the "Tradition" essay. Eliot may not be wholly consistent in his use of the terms "emotion" and "feeling," but the central point of his argument is that the artistic process of creation entails an objectivisation of emotion through the object or image. Both emotion/object and feeling/image essentially present the same depersonalized or "artistic emotion." Indeed, the lurking presence of Schopenhauer in these two foremost of Eliot's critical formulations - the catalytic mind of the poet and the objective correlative - is substantiated by the fact that Section 51 of WWR I offers an account of emotion in art closely analogous to Eliot's.

Considered broadly, the question of emotion in Schopenhauer's aesthetics poses something of a problem. For Schopenhauer, all emotion, "wishing, shunning, hoping, fearing, loving, hating...desire and disinclination, is obviously only affection of the will, is a stirring, a modification, of willing and not-willing" (WWR II, p. 202). As Julian Young observes, Schopenhauer's conception of emotions as modifications of the will, and aesthetic experience as will-less perception, seemingly suggests an aesthetics that excludes emotion from art. (9) However, as Young points out, an analysis of the role of emotion in art can be found in two sections of WWR ISchopenhauer's discussion of the sublime (which evaluates the place of emotion in the response to art) and his discussion of lyric poetry (in which he treats the question of emotion in artistic creation). According to Schopenhauer, the sublime is experienced when the very objects which invite pure contemplation are seen to have a hostile relation to the human will. In this case, the beholder struggles to consciously turn away from the will and its relations; in doing so he 
experiences an elevation above "himself, his person, his willing, and all willing" (WWR I, p. 201), and this is the feeling of the sublime. This exaltation must be maintained and is therefore "accompanied by a constant recollection of the will, yet not of a single individual willing, such as fear or desire, but of human willing in general" (WWR I, p. 202). This elevation, as described by Schopenhauer, is effectively a depersonalization; Schopenhauer is suggesting the experience of the sublime to be predicated on a conscious detachment from emotion that yet allows for a "recollection" or contemplation of the human condition of willing. At this point, we can perhaps already hear intimations of Eliot's poetics of impersonality. But this becomes clearer when considered within the context of Section 51 of $W W R$, which increasingly suggests itself as the epicentre within a terrain of unacknowledged influence.

As Young observes, Schopenhauer's discussion of lyric poetry offers the same pattern of analysis seen in his discussion of the sublime. In both cases, Schopenhauer suggests the operation of a kind of dissociated emotion and this repetition strongly suggests that Schopenhauer is offering a general account of emotion in art. (Young, p. 123) If, in the case of the sublime object, the question of emotion seems something of a side affair, Schopenhauer's analysis of the lyrical state puts emotion right at the centre of the discussion. Poetry, Schopenhauer suggests, chiefly expresses the Idea of mankind: while the plastic and pictorial arts are often better suited to reveal the Ideas of nature, man is "the principal subject of poetry," for he expresses himself through "a chain of actions and of the accompanying thoughts and emotions" (WWR I, p. 244). Lyric poetry in particular, Schopenhauer suggests, deals with the subject of the will always as emotion. Indeed, despite his general emphasis on objectivity as the grounds of artistic genius, Schopenhauer acknowledges that lyric poetry requires a certain subjectivity through its very object; for here, the depicter is also the depicted. This also means that for Schopenhauer lyric poetry becomes the easiest poetic form, requiring only a vivid perception of one's own emotional state. But, as Schopenhauer goes on to clarify, many such lyric compositions are inferior in standard. The great lyric poet, he argues, is instead the "universal man," whose lyrics reflect "the inner nature of the whole of mankind" (WWR I, p. 249). Of such great lyric poetry Schopenhauer writes

It is the subject of the will, in other words, the singer's own willing, that fills his consciousness... always as emotion, passion, an agitated state of mind. Besides this, however, and simultaneously with it, the singer, through the sight of surrounding nature, becomes conscious of himself as the subject of pure, will-less knowing, whose unshakable, blissful peace now appears in contrast to the stress of willing that is always restricted and needy. The feeling of this contrast, this alternate play, is really what is expressed in the whole of the song, and what in general constitutes the lyrical state... The genuine song is the expression or copy of the whole of this mingled and divided state of mind. (WWR I, p. 250)

So here we have nearly all the tenets of Eliot's impersonal theory of poetry: universalised, 
depersonalised emotion, and an inner tension between emotions felt yet transformed by the chemically unreactive "mind" of the poet. Indeed, though the word "universal" does not appear in the "Tradition" essay, it is a small step to redefine tradition as a kind of universal memory; hence "significant emotion" is "emotion which has its life in the poem and not in the history of the poet" and in relation to "the present moment of the past" (p. 22). In his 1927 essay on Shakespeare, Eliot restates these terms, describing "the struggle - which alone constitutes life for a poet - to transmute his personal and private agonies into something rich and strange, something universal and impersonal." (10) That there is a striking affinity between Eliot and Schopenhauer seems scarcely in doubt; Eliot's early formulation of impersonal emotion is precisely the "twofold" or "mingled and divided state of mind" that is Schopenhauer's account of emotion in lyric poetry. As Eliot writes in his student dissertation, anticipating his 1919 essays, "To say that one part of the mind suffers and another part reflects upon the suffering is perhaps to talk in fictions. But we know that those highlyorganised beings who are able to objectify their passions, and as passive spectators to contemplate their joys and torments, are also those who suffer and enjoy the most keenly." (11) The question again is one of objectifying passions or, in Eliot's later terminology, the objective correlative of emotion.

In this growing picture of resemblances and affiliations, we come to yet another altogether curious point of contact between Eliot's essays of 1919 and Schopenhauer's aesthetics of poetry. In Section 51 of $W W R$ I, Schopenhauer summarises the lyrical state as one in which willing and pure perception of the world environment are delightfully merged with each other. He immediately goes on to observe that this lyrical state is, in essence, "the perceptive and poetical knowledge" of a certain principle advanced in his earlier work of 1813; namely that "the identity of the subject of knowing with the subject of willing can be called the miracle [par excellence]" (WWR I, p. 251). In other words, Schopenhauer effectively defines lyric poetry in specific relation to this principle; in its treatment of emotion, lyric poetry enacts the miraculous identity between willing and knowing. Turning to the relevant passage of Schopenhauer's On the Fourfold Root of the Principle of Sufficient Reason we read, "But whoever really grasps the inexplicable nature of this identity, will with me call it the miracle "par excellence" [Tr.]. / Now just as the subjective correlative to the first class of representations is the understanding...so is the subjective correlative to this fourth class found to be the inner sense, or generally self-consciousness." (12) With Eliot in mind, reading this passage in Schopenhauer brings a degree of astonishment; for the very idea of a subjective correlative naturally raises the spectre of an objective correlative. Indeed, a further turn back through the pages of Schopenhauer's On the Principle of Sufficient Reason reveals this corresponding statement: "Matter is therefore only the objective correlative of the pure 
understanding" (PSR, p. 119).

In my view, the evidence seems sufficient not only for an anxiety of influence but for a rather more damning verdict. Reviewing the discussion, we see that Schopenhauer's treatment of the aesthetics of poetry in Section 51 of WWR I answers the question of emotion in art with direct reference to a specific principle - that of the identity of the subject of willing with the subject of knowing. In his earlier work of 1813, Schopenhauer explains this principle through the structures of subjective and objective correlatives. Moreover, for Schopenhauer, pure understanding and pure perception are closely related; so if lyric poetry miraculously blends willing with pure perception of the environment, this means a merging of the interior state of willing with the objective correlative that Schopenhauer locates in matter. Eliot's formulation of the objective correlative (notwithstanding the direct use of the translated term) similarly treats the very same question of emotion in art and, in like manner, suggests this correlative to be located in the object, that is, in matter. Furthermore, Eliot's "Tradition" essay and Section 51 of WWR I both offer striking formulations of the poet as chemist and the making of poetry as an objective chemistry predicated on the image. If Schopenhauer assesses the role of emotion in poetry both with respect to its universality and in terms of an interior "twofold" process of cognition, this dual explanation is repeated in what Eliot himself describes the two aspects of his impersonal theory of poetry (namely, the relation of the poem to tradition and the relation of the poem to its author).

We may end perhaps with what can only be read, on Eliot's part, as an attempted and anxious denial. In "Tradition and the Individual Talent," Eliot proffers his chemical analogy of the mind of the poet and shortly after observes, "you see...how completely any semi-ethical criterion of 'sublimity' misses the mark. For it is not the 'greatness', the intensity, of the emotions, the components, but the intensity of the artistic process...that counts.” (p. 19) In these lines, Eliot alludes directly to Schopenhauer, but in an altogether dishonest way. As is well known, Schopenhauer both explicitly and inexplicitly connects his aesthetic philosophy with his ethics of compassion and renunciation. He famously suggests that the decision to affirm or deny the will is the only true and defining "event in-itself" (WWR I, p. 184). Accordingly, since aesthetic experience is the only way to gain true understanding of the Ideas and of the will, this means that aesthetic experience is necessary for making the ultimate ethical choice of affirmation or denial. The particular ethical relevance of the sublime becomes clear in Schopenhauer's treatment of tragedy where he suggests that "the effect of the tragedy is analogous to that of the dynamically sublime, since, like this, it raises us above the will and its interest, and puts us in such a mood that we find pleasure in the sight of what directly opposes the will" (WWR II, p. 433). By conjuring up 
Schopenhauer's "semi-ethical criterion of sublimity" Eliot engages in a sly misrepresentation which enables him to put his nineteenth-century predecessor on the wrong side of the argument. On the one hand, Eliot presents a line-up of sublimity, morality, high emotion; on the other, the iconoclastic new science of poetry, raised upon the building blocks of objectivity and impersonality. What becomes explicit in his 1926 lectures on metaphysical poetry is implicit too here in "Tradition and the Individual Talent" - the dismissive presentation of Schopenhauer as irretrievably "emotional." It seems difficult not to conclude that Eliot's presentation of the philosopher is anything other than a deliberately calculated deflection away from the connections between Schopenhauer's aesthetics of poetry and Eliot's modernist poetics of impersonal emotion and the objective correlative.

1. T. S. Eliot, The Varieties of Metaphysical Poetry, ed. R. Schuchard (London: Faber and Faber Ltd., 1993), p. 215.

2. Varieties of Metaphysical Poetry, p. 222.

3. After Strange Gods quoted in C. M. Kearns, T. S. Eliot and Indic Traditions (Cambridge: CUP, 1987), p. 95.

4. J. M. Kertzer, “T. S. Eliot and the Problem of Will," MLQ 45, no. 4 (1984): 373-394.

5. A. Schopenhauer, The World as Will and Representation, trans. E. F. J. Payne (New York: Dover Publications, Inc., 1969), vol. 1, p. 171; hereafter abbreviated WWR.

6. C. Foster, "Schopenhauer on the Proper Foundation of Art," in The Cambridge Companion to Schopenhauer (Cambridge: CUP, 1999), p. 232.

7. T. Lütkemeier, Chez soi: the Aesthetic Self in Arthur Schopenhauer, Walter Pater and T. S. Eliot ((Würzburg: Königshausen \& Neumann, 2001), p. 268.

8. T. S. Eliot, "Tradition and the Individual Talent," in Selected Essays (London: Faber and Faber Ltd., 1932), p. 18; hereafter after abbreviated Essays.

9. J. Young, Schopenhauer (New York: Routledge, 2005), p. 114.

10. T. S. Eliot, "Shakespeare and the Stoicism of Seneca" in Elizabethan Essays (London: Faber \& Faber, 1934), p. 49.

11. T. S. Eliot, Knowledge and Experience in the philosophy of F. H. Bradley (London: Faber and Faber, 1964), p. 23. This is the published version of Eliot's 1914 doctoral dissertation at Harvard, originally entitled Experience and the Objects of Knowledge in the Philosophy of F. H. Bradley.

12. A. Schopenhauer, On the Fourfold Root of the Principle of Sufficient Reason (Peru: Open Court Publishing Co., 1974), pp. 211-12; hereafter abbreviated PSR. 